\title{
Effect of Row Spacing and Phosphorus Fertilizer Rates on Yield and Yield Related Traits of Mung Bean (Vigna radiata L.) at Fedis, Eastern Ethiopia
}

\author{
Gezu Degefa ${ }^{1, *}$, Abdulatif Ahmad², Ketema Belete ${ }^{2}$ \\ ${ }^{1}$ Fedis Agricultural Research Center, Oromia Agricultural Research Institute, Harar, Ethiopia \\ ${ }^{2}$ School of Plant Sciences, College of Agriculture and Environmental Sciences, Haramaya University, Haramaya, Ethiopia
}

Email address:

gezudedefa@gmail.com (G. Degefa)

${ }^{*}$ Corresponding author

\section{To cite this article:}

Gezu Degefa, Abdulatif Ahmad, Ketema Belete. Effect of Row Spacing and Phosphorus Fertilizer Rates on Yield and Yield Related Traits of Mung Bean (Vigna radiata L.) at Fedis, Eastern Ethiopia. Journal of Plant Sciences. Vol. 9, No. 2, 2021, pp. 65-70.

doi: 10.11648/j.jps.20210902.15

Received: January 26, 2021; Accepted: April 16, 2021; Published: April 29, 2021

\begin{abstract}
Determination of appropriate row spacing and phosphorus rate of mung bean can increase its productivity. Therefore, a field experiment was conducted at Fedis Agricultural Research Center during main growing season to evaluate the effect of phosphorus rate and row spacing on yield and yield related traits of mung bean. Factorial combinations of four phosphorus rate $\left(0,23,46,69 \mathrm{~kg} \mathrm{P}_{2} \mathrm{O}_{5} \mathrm{ha}^{-1}\right)$ and three row spacing $(20,30$, and $40 \mathrm{~cm})$ laid out in RCBD with three replications. A total of 12 treatments and Borda variety was used for the experiment. The results revealed that there were significant $(\mathrm{P}<0.05)$ differences for plant height, total and effective number of nodule plant ${ }^{-1}$, pod plant ${ }^{-1}$, thousand grain weight, dry biomass yield and grain yield due to phosphorus application. Branch per plant, pod per plant, pod length and dry biomass yield were significantly $(\mathrm{P}<0.05)$ affected due to row spacing. The highest Thousand Grain Weight $(30.18 \mathrm{~g})$ was obtained from the application of $46 \mathrm{~kg} \mathrm{P}_{2} \mathrm{O}_{5} \mathrm{ha}^{-1}$ while the lowest $(28.27 \mathrm{~g})$ was obtained from $0 \mathrm{~kg} \mathrm{P}_{2} \mathrm{O}_{5} \mathrm{ha}^{-1}$. The highest grain yield $\left(961.6 \mathrm{~kg} \mathrm{ha}^{-1}\right)$ was achieved from $46 \mathrm{~kg} \mathrm{P}_{2} \mathrm{O}_{5} \mathrm{ha}^{-1}$ while the lowest $\left(766.7 \mathrm{~kg} \mathrm{ha}^{-1}\right)$ was from $0 \mathrm{P}_{2} \mathrm{O}_{5}$. In conclusion, the application of $46 \mathrm{~kg} \mathrm{P}_{2} \mathrm{O}_{5} \mathrm{ha}^{-1}$ and $30 \mathrm{~cm}$ row spacing recorded highest grain yield with highest economic returns $\left(14123.78 \mathrm{ETB} \mathrm{ha}^{-1}\right)$. Based on grain yield and economic return, combination of $46 \mathrm{~kg} \mathrm{P}_{2} \mathrm{O}_{5} \mathrm{ha}^{-1}$ and $30 \mathrm{~cm}$ row spacing was recommended for the study area and similar agro-ecology.
\end{abstract}

Keywords: Row Spacing, Mung Bean, Phosphorus, Yield

\section{Introduction}

Mung bean (Vigna radiata L.) also known as Green gram is a self-pollinated leguminous crop and is among the most important pulse crops of the world. It has great value as food, fodder and green manure. This crop can be successfully grown on marginal lands where other crops perform poorly [7]. It is a fast-growing, warm-season legume.

Optimum row spacing plays an important role in contributing to the high yield because thick plant population will not get proper light for photosynthesis and can easily be attacked by diseases. On the other hand, very small population will also reduce the yield [16]. Improper spacing reduces the yield of mung bean up to $20-40 \%$ [4] due to competition for light, space, water and nutrition. Optimum plant spacing and seed rate should be ensured for the plant to grow properly in order to give higher yield [15].

Research on crop nutrition has documented nitrogen and phosphorus as the most limiting nutrient elements for crop production [14]. However, $\mathrm{P}$ has been reported to be more limiting than $\mathrm{N}$ in tropical legumes [10]. Nodulation and $\mathrm{N}$ fixation for tropical legumes and survival of Rhizobia in soil are particularly affected under low $\mathrm{P}$ and acid soil conditions [8].

One of the major constraints that limit the production of mung bean is a lack of optimum plant populations and soil fertility status. As a number of factors such as fertility status of the soil, moisture availability, salinity stress, growth pattern of the variety and cultural practices influence 
optimum planting density and phosphorus rate should be determined to specific area and to specific mung bean variety through conducting location or agro-ecology based experiment [9]. The objectives of the study were to evaluate the effect of row spacing and phosphorus rate on yield and yield related traits of mung bean.

\section{Materials and Methods}

\subsection{Description of the Study Area}

The experiment was conducted at Fedis Agricultural Research Center, Boko experimental site in Fedis district, east Hararghe Zone of Oromia region. Boko experimental site is located at the latitude of $9^{\circ} 07^{\prime} \mathrm{N}$ and longitude of $42^{\circ}$ 04' East, in the middle and low land areas and at average altitude of 1702 meter above sea level, with a prevalence of low lands. The district receives average annual rain fall of $860.4 \mathrm{~mm}$; the minimum and maximum air temperature of $20^{\circ} \mathrm{C}$ and $35^{\circ} \mathrm{C}$, respectively.

\subsection{Description of Experimental Materials}

Improved variety of mung bean Borda (MH-97-6) was used as a test crop. It is drought tolerant, disease resistant and high yielding variety. It has 0.8 to 2.4 ton/ha yield potential and 60-70 days to maturity and well adapted and popularized around the study areas. Triple super phosphate (TSP) was drilled in the row as per the treatment and mixed with soil just at the time of planting.

\subsection{Treatments and Experimental Design}

The treatments consisted of factorial combination of four fertilizer rate $\left(0,23,46\right.$ and $69 \mathrm{~kg} \mathrm{ha}^{-1}$ of $\left.\mathrm{P}_{2} \mathrm{O}_{5}\right)$ as triple super phosphate (TSP) and three row spacing (20, 30 and $40 \mathrm{~cm})$. The experiment was laid out in Randomized Complete Block Design (RCBD) and replicated three times per treatment in factorial combination with a total of 12 treatments.

\subsection{Experimental Procedures}

The land was ploughed by tractor, disked, harrowed and finally all plots was manually leveled for precise planting. Starter fertilizer $20 \mathrm{~kg} \mathrm{ha}^{-1}$ of urea was uniformly drilled in the row to all treatments and mixed with soil just at the time of planting. The plot size was $2.5 \mathrm{~m}$ by $2.4 \mathrm{~m}$. The experiment consists of 6,8 and 12 rows for 40,30 and $20 \mathrm{~cm}$ row spacing respectively. The spacing between blocks and plots was $1 \mathrm{~m}$ and $0.6 \mathrm{~m}$ respectively. The border row was used as destructive rows and the middle rows were used for data collection. Two seeds was per hill and then thinned to one plant three weeks after seedling emerge. All other management practices were given as per the recommendations.

\subsection{Data Management and Analysis}

\subsubsection{Data Collected}

Data collected were plant height, number of branch, number of nodules, effective nodule per plant, number of pod, pod length, number of seed per pod, hundred grain weights, biomass yield and grain yield.

\subsubsection{Data Analysis}

All the measured parameters were subjected to analysis of variance (ANOVA) appropriate to factorial experiment in RCBD according to the General Linear Model (GLM) of Gen Stat $15^{\text {th }}$ edition (Gen Stat, 2015). LSD test at $5 \%$ probability level was used for mean comparison when the ANOVA showed significant differences.

\section{Results and Discussion}

\subsection{Soil Physico-Chemical Properties of the Experimental Site}

The analysis result of the collected soil sample from the experimental site (Table 1) indicated that the soil was clay with a particle size distribution of $23 \%$ sandy, $29 \%$ silt and $48 \%$ clay with $\mathrm{pH}$ value of 8.1 which is slightly alkaline. The soil was medium in total nitrogen $(0.167 \%)$, had low available phosphorus (2.61 $\mathrm{mg} \mathrm{kg}^{-1}$ soil), moderate organic matter (2.277) contents and low cation exchange capacity (7.13 cmol kg-1 soil) according to range [20].

Table 1. Selected soil physico-chemical properties of the experimental site

\begin{tabular}{llllll}
\hline Parameter & pH & CEC & OC & Avail. P & TN \\
\hline Value & 8.1 & 23.304 & 1.268 & 2.61 & Texture \\
\hline
\end{tabular}

\subsection{Plant Height}

Analysis of variance showed that plant height was significantly $(\mathrm{P}<0.05)$ influenced by the main effect of phosphorus. However, the main effect of row spacing and their interactions were not significant. The tallest plant height $(29.93 \mathrm{~cm})$ was recorded from application of $69 \mathrm{~kg} \mathrm{P}_{2} \mathrm{O}_{5} \mathrm{ha}^{-1}$, which was statistically similar with $46 \mathrm{~kg} \mathrm{P}_{2} \mathrm{O}_{5}$ ha $^{-1}$ while the shortest plant height $(26.96 \mathrm{~cm})$ was obtained when the plants were not treated with $\mathrm{P}_{2} \mathrm{O}_{5}$ (Table 2).

The result is in line with Imran, Asad, Inamullah, and
Fayaz [11] who reported Plots treated with $60 \mathrm{~kg} \mathrm{P} \mathrm{ha}{ }^{-1}$ produced taller plants height, being at par with 80 and $100 \mathrm{~kg}$ $\mathrm{P} \mathrm{ha}{ }^{-1}$ while shorter plants height was recorded in control plots. Similarly Kumar, Singh, Singh, Latare, Mishra and Supriya [13] reported Plant height increased continuously and significantly with increasing levels of phosphorus up to $45 \mathrm{~kg} \mathrm{P}_{2} \mathrm{O}_{5} \mathrm{ha}^{-1}$ at all stages of crop growth.

\subsection{Number of Branches per Plant}

There was significant $(\mathrm{P}<0.05)$ difference in number of branches per plant due to the main effect of row spacing 
while, the main effect of phosphorus and their interaction had no significant effect. The highest number of branch per plant (4.767) was obtained from the row spacing of $40 \mathrm{~cm}$ which was statistically similar with $30 \mathrm{~cm}$ and the lowest number of branch per plant (4.125) was obtained from $20 \mathrm{~cm}$ (Table 2).

The finding is in agreement with Gebrelibanos Gebremariam and Fiseha Baraki [6] who reported the highest numbers of branches per plant were recorded from $30 \mathrm{~cm}$ and $40 \mathrm{~cm}$ inter-row spacing whereas the lowest was obtained from $20 \mathrm{~cm}$ inter-row spacing.

\subsection{Number of Nodules and Effective Nodule per Plant}

The main effects of phosphorus application significantly $(\mathrm{P}<0.05)$ affected the total number of nodules per plant, however, the main effect of row spacing and their interaction had no significant effect. The highest total number of nodule per plant (3.83) was obtained from plants grown under P rate of 69 and $46 \mathrm{~kg} \mathrm{P}_{2} \mathrm{O}_{5} \mathrm{ha}^{-1}$, while, the lowest (2.44) was observed under control treatment (Table 2). The improvement in nodule number due to $\mathrm{P}$ fertilizer could be associated with its stimulating effect on growth [19].

The analysis of variance revealed that the main effects of phosphorus application significantly $(\mathrm{P}<0.05)$ affected the effective number of nodule per plant, while, the main effect of row spacing and their interaction had no significant effect. The highest effective number of nodule plant $^{-1}$ (3.28) was obtained from plants grown under $\mathrm{P}$ rate of $69 \mathrm{~kg} \mathrm{P}_{2} \mathrm{O}_{5} \mathrm{ha}^{-1}$, while the lowest (1.94) was observed under control treatment (Table 2).

In addition to the nodule formation, deficiency of phosphorus in legume also markedly reduced the development of effective nodules and the nodule leghaemoglobin content which is responsible for the formation of dark pink or red centers inside nodules [18].

Table 2. The means of plant height, branches per plant, nodule per plant and effective nodule per plant as influenced by the main effect of phosphorus and row spacing.

\begin{tabular}{lllll}
\hline $\mathbf{P}_{\mathbf{2}} \mathbf{O}_{\mathbf{5}}\left(\mathbf{k g ~ h a}^{-\mathbf{1}}\right)$ & Plant Height & branch Plant $^{-1}$ & nodule Plant $^{-1}$ & Effective nodule plant $^{-1}$ \\
\hline 0 & $26.96^{\mathrm{c}}$ & 4.411 & $2.44^{\mathrm{a}}$ & $1.94^{\mathrm{a}}$ \\
23 & $27.34^{\mathrm{bc}}$ & 4.5 & $2.61^{\mathrm{a}}$ & $2.17^{\mathrm{a}}$ \\
46 & $29.53^{\mathrm{ab}}$ & 4.478 & $3.83^{\mathrm{b}}$ & $3.11^{\mathrm{b}}$ \\
69 & $29.93^{\mathrm{a}}$ & 4.533 & $3.83^{\mathrm{b}}$ & $3.28^{\mathrm{b}}$ \\
LSD (5\%) & 2.331 & $\mathrm{NS}$ & 0.82 & 0.49 \\
row spacing (cm) & & & \\
20 & 28.74 & $4.125^{\mathrm{b}}$ & 3.17 & 2.58 \\
30 & 28.54 & $4.55^{\mathrm{ab}}$ & 3.08 & 2.5 \\
40 & 28.05 & $4.767^{\mathrm{a}}$ & 3.29 & 2.79 \\
LSD (5\%) & $\mathrm{NS}$ & 0.4496 & $\mathrm{NS}$ & $\mathrm{NS}$ \\
CV (\%) & 12.2 & 38.7 & 27.8 \\
\hline
\end{tabular}

Means followed by the same letter (s) are not significantly different at $5 \%$ level of significance for each treatments; LSD = Least Significant difference; $\mathrm{CV}=$ Coefficient of Variation.

\subsection{Number of Pods per Plant}

The analysis of variance revealed that main effect of row spacing and phosphorus rate were significant $(\mathrm{P}<0.05)$ on the number of pod plant ${ }^{-1}$. However, the interaction effect was not significant. The highest Number of pod per plant (19.27) was obtained from row spacing of $40 \mathrm{~cm}$ which was statistically similar with $30 \mathrm{~cm}$ while the lowest (15.32) was obtained from $20 \mathrm{~cm}$ row spacing and the highest number of pod per plant (18.93) was obtained from $46 \mathrm{~kg} \mathrm{P}_{2} \mathrm{O}_{5} \mathrm{ha}^{-1}$ and the lowest (15.71) was from when there was no $\mathrm{P}_{2} \mathrm{O}_{5}$ application (Table 3 ).

The current result is in line with Ajio, Talwana and Kagoda [2] who reported plants sown at a spacing of $40 \times 10$ $\mathrm{cm}$ had the highest average number of pods (16.18).

\subsection{Pod Length and Number of Seed per Pod}

The analysis of variance showed significance differences $(\mathrm{P}<0.05)$ as affected by row spacing while, the main effects of phosphorus and their interaction were not significant. The highest pod length $(7.742 \mathrm{~cm})$ was recorded in $30 \mathrm{~cm}$ inter row spacing while the lowest pod length $(7.162 \mathrm{~cm})$ was from $20 \mathrm{~cm}$ (Table 3 ).
The present finding consisted with Foysalkabir, Quamruzzaman, Mohammed, Rashid, Yeasmin and Islam [5] who reported the maximum pod length $(10.18 \mathrm{~cm})$ was obtained from $30 \mathrm{~cm} \times 10 \mathrm{~cm}$ spacing whereas, the minimum $(6.38 \mathrm{~cm})$ was observed from $20 \mathrm{~cm} \times 10 \mathrm{~cm}$ spacing.

Analysis of variance showed that the main effect and their interaction effect on number of seed per pod were not significant (Table 3). Fertilizer application and wider plant spacing increased the number of seeds pod $^{-1}$, but the variation was not up to the mark statistically.

\subsection{Thousand Grain Weight}

The analysis of variance revealed application of phosphorus significantly $(\mathrm{P}<0.05)$ affected thousand grain weights. While, the main effect of row spacing and their interaction effect was not significantly influenced. The highest thousand grain weight $(30.18 \mathrm{~g})$ was obtained from the application of $46 \mathrm{~kg} \mathrm{P}_{2} \mathrm{O}_{5} \mathrm{ha}^{-1}$ while the lowest $(28.27 \mathrm{~g})$ was obtained from the control plot (Table 3). The current result is in line with Khan, Singh and Kumar [12] reported maximum test weight was recorded with $45 \mathrm{~kg} \mathrm{P}_{2} \mathrm{O}_{5} \mathrm{ha}^{-1}$ followed with $30 \mathrm{~kg} \mathrm{P}_{2} \mathrm{O}_{5} \mathrm{ha}^{-1}$, whereas, the minimum remained with $0 \mathrm{~kg} \mathrm{P}_{2} \mathrm{O}_{5} \mathrm{ha}^{-1}$. 
Table 3. The means of pod per plant, Pod length, seed per pod and thousand grain weight as influenced by the main effect of phosphorus and row spacing

\begin{tabular}{|c|c|c|c|c|}
\hline $\mathrm{P}_{2} \mathrm{O}_{5}\left(\mathrm{~kg} \mathrm{ha}^{-1}\right)$ & Pod plant $^{-1}$ & Pod length & Seed pod ${ }^{-1}$ & 1000 grain weight \\
\hline 0 & $15.71^{\mathrm{b}}$ & 7.278 & 11.19 & $28.27^{\mathrm{b}}$ \\
\hline 23 & $17.72^{\mathrm{ab}}$ & 7.361 & 11.28 & $28.32^{\mathrm{b}}$ \\
\hline 46 & $18.93^{\mathrm{a}}$ & 7.583 & 11.2 & $30.18^{\mathrm{a}}$ \\
\hline 69 & $18.68^{\mathrm{a}}$ & 7.633 & 11.74 & $29.06^{\mathrm{ab}}$ \\
\hline $\begin{array}{l}\text { LSD }(5 \%) \\
\text { row spacing }(\mathrm{cm})\end{array}$ & 2.285 & NS & NS & 1.147 \\
\hline 20 & $15.32^{\mathrm{b}}$ & $7.162^{\mathrm{b}}$ & 10.99 & 28.3 \\
\hline 30 & $18.69^{\mathrm{a}}$ & $7.742^{\mathrm{a}}$ & 11.48 & 29.25 \\
\hline 40 & $19.27^{\mathrm{a}}$ & $7.487^{\mathrm{ab}}$ & 11.58 & 29.33 \\
\hline LSD (5\%) & 1.979 & 0.393 & NS & NS \\
\hline CV (\%) & 19.2 & 9.1 & 9.3 & 5.9 \\
\hline
\end{tabular}

Means within the same column followed by the same letter (s) are not significantly different at $5 \%$ level of significance; LSD=Least Significant difference; $\mathrm{NS}=$ Not significant; $\mathrm{CV}=$ Coefficient of Variation.

\subsection{Above Ground Dry Biomass}

Above ground dry biomass was significantly $(\mathrm{P}<0.05)$ influenced by the main effect of row spacing and phosphorus application. While, there was no significant effect of their interactions. The highest above ground dry biomass $(2556 \mathrm{~kg}$ $\mathrm{ha}^{-1}$ ) was achieved under the application of $46 \mathrm{~kg} \mathrm{P}_{2} \mathrm{O}_{5} \mathrm{ha}^{-1}$. The treatment without $\mathrm{P}_{2} \mathrm{O}_{5}$ application resulted in the lowest above ground dry biomass $\left(2023 \mathrm{~kg} \mathrm{ha}^{-1}\right)$. The highest and lowest above ground dry biomass $\left(2424 \mathrm{~kg} \mathrm{ha}^{-1}\right)$ and (2103 $\mathrm{kg} \mathrm{ha}^{-1}$ ) was also obtained under $20 \mathrm{~cm}$ and $40 \mathrm{~cm}$ row spacing respectively (Table 4).

This result is agreement with Amanullah, Majidullah, Muhammad, Nawab and Ali [3] who reported Phosphorus levels had significant impact on biomass yield of mung bean under dry land condition. Similarly, Kumar, Singh, Singh, Latare, Mishra and Supriya [13] reported there was rise in straw yield with increasing doses of phosphorus.

In the case of row spacing Rasul, Cheema, Sattar, Saleem, and Wahid [17] reported that the row spacing of $30 \mathrm{~cm}$ and $45 \mathrm{~cm}$ produced dry biomass of $4131 \mathrm{~kg} \mathrm{ha}^{-1}$ and $4003.5 \mathrm{~kg}$ $\mathrm{ha}^{-1}$ while, the wider spacing of $60 \mathrm{~cm}$ resulted in minimum dry biomass $\left(3328.9 \mathrm{~kg} \mathrm{ha}^{-1}\right)$.

\subsection{Grain Yield}

The analysis of variance revealed the main effect of phosphorus application was significant difference $(\mathrm{P}<0.05)$. However, the main effect of row spacing and their interaction were not significant difference. The highest grain yield (961.6 $\mathrm{kg} \mathrm{ha}^{-1}$ ) was achieved from $46 \mathrm{~kg} \mathrm{P}_{2} \mathrm{O}_{5} \mathrm{ha}^{-1}$ while the lowest grain yield $\left(766.7 \mathrm{~kg} \mathrm{ha}^{-1}\right)$ was obtained from control treatment (Table 4).

Table 4. The means of dry biomass and grain yield as influenced by the main effect of phosphorus and row spacing.

\begin{tabular}{lll}
\hline $\mathbf{P}_{\mathbf{2}} \mathbf{O}_{\mathbf{5}}\left(\mathbf{k g ~ h a}^{\mathbf{- 1}}\right)$ & Dry biomass yield & Grain Yield $\mathbf{( k g} / \mathbf{h a})$ \\
\hline 0 & $2023^{\mathrm{c}}$ & $766.7^{\mathrm{c}}$ \\
23 & $2184^{\mathrm{bc}}$ & $822.1 \mathrm{~b}^{\mathrm{c}}$ \\
46 & $2556^{\mathrm{a}}$ & $961.6^{\mathrm{a}}$ \\
69 & $2396^{\mathrm{ab}}$ & $911.5^{\mathrm{ab}}$ \\
LSD $(5 \%)$ & 270.715 & 97.9 \\
Inter row (cm) & & \\
20 & $2424^{\mathrm{a}}$ & 904 \\
30 & $2341^{\mathrm{a}}$ & 886 \\
40 & $2103^{\mathrm{b}}$ & 807 \\
LSD $(5 \%)$ & 234.446 & $\mathrm{NS}$ \\
CV $(\%)$ & 17.6 & 16.9 \\
\hline
\end{tabular}

Means followed by the same letter (s) are not significantly different at $5 \%$ level of significance for each treatments; LSD = Least Significant difference; CV= Coefficient of Variation.

The result is in line with Kumar, Singh, Singh, Latare, Mishra and Supriya [13] Maximum value of $10.78 \mathrm{q} \mathrm{ha}^{-1}$ grain yield was recorded at $45 \mathrm{~kg} \mathrm{P}_{2} \mathrm{O}_{5} \mathrm{ha}^{-1}$ and minimum value of $7.32 \mathrm{q} \mathrm{ha}^{-1}$ grain yield was recorded at $0 \mathrm{~kg} \mathrm{P}_{2} \mathrm{O}_{5} \mathrm{ha}^{-1}$ Similarly Ahmad, Khan, Ali, Imran and Habibullah [1] reported mean value of phosphorus levels indicated that plots treated with $80 \mathrm{~kg} \mathrm{P} \mathrm{ha}{ }^{-1}$ produced maximum grain yield (1139 $\mathrm{kg} \mathrm{ha}^{-1}$ ) being at par with $100 \mathrm{~kg} \mathrm{P} \mathrm{ha}^{-1}$, while minimum grain yield $\left(617 \mathrm{~kg} \mathrm{ha}^{-1}\right)$ was recorded in control plots.

\subsection{Partial Budget Analysis}

Application of phosphorus rate at $46 \mathrm{~kg} \mathrm{ha}^{-1}$ and row spacing of $30 \mathrm{~cm}$ recorded maximum net benefit with acceptable marginal rate of returns followed by combination of $69 \mathrm{~kg} \mathrm{ha}^{-1}$ and $20 \mathrm{~cm}$ from mung bean production. The lowest net returns were obtained at $0 \mathrm{P}_{2} \mathrm{O}_{5} \mathrm{~kg} \mathrm{ha}^{-1}$ in all treatment combinations. 
Table 5. Summary of economic analysis of the effects of phosphorus rates and row spacing.

\begin{tabular}{|c|c|c|c|c|c|c|c|}
\hline Treatments & row spacing & UGY (kg ha-1) & $\operatorname{AGY}\left(\mathrm{kg} \mathrm{ha}^{-1}\right)$ & GFB (ETB ha-1) & TVC $\left(\right.$ ETBha $\left.^{-1}\right)$ & NB $($ ETB ha-1) & MRR (\%) \\
\hline \multicolumn{8}{|c|}{$\mathrm{P}_{2} \mathrm{O}_{5}\left(\mathrm{~kg} \mathrm{ha}^{-1}\right)$} \\
\hline 0 & 40 & 601.85 & 541.665 & 10833.3 & 640 & 10193.3 & \\
\hline 0 & 30 & 673.81 & 606.429 & 12128.58 & 925 & 11203.58 & 354.4842 \\
\hline 0 & 20 & 744.44 & 669.996 & 13399.92 & 1210 & 12189.92 & 346.0842 \\
\hline 23 & 40 & 680.56 & 612.504 & 12250.08 & 1537 & 10713.08 & $\mathrm{D}$ \\
\hline 23 & 30 & 864.29 & 777.861 & 15557.22 & 1822 & 13735.22 & 1060.4 \\
\hline 23 & 20 & 857.64 & 771.876 & 15437.52 & 2107 & 13330.52 & $\mathrm{D}$ \\
\hline 46 & 40 & 843.52 & 759.168 & 15183.36 & 2434 & 12749.36 & $\mathrm{D}$ \\
\hline 46 & 30 & 935.71 & 842.139 & 16842.78 & 2719 & 14123.78 & 482.2526 \\
\hline 46 & 20 & 949.31 & 854.379 & 17087.58 & 3004 & 14083.58 & $\mathrm{D}$ \\
\hline 69 & 40 & 865.74 & 779.166 & 15583.32 & 3331 & 12252.32 & $\mathrm{D}$ \\
\hline 69 & 30 & 829.37 & 746.433 & 14928.66 & 3616 & 11312.66 & $\mathrm{D}$ \\
\hline 69 & 20 & 996.53 & 896.877 & 17937.54 & 3901 & 14036.54 & 955.7474 \\
\hline
\end{tabular}

Where, $\mathrm{P}=$ Phosphorus $\left(\mathrm{P}_{2} \mathrm{O}_{5}\right)$ rate $\left(\mathrm{kg} \mathrm{ha}^{-1}\right) ; \mathrm{R}=$ row spacing $(\mathrm{cm})$; UGY = Unadjusted grain yield; AGY = adjusted grain yield; GFB = gross field benefit; $\mathrm{TVC}=$ total variable cost $\mathrm{NB}=$ net benefit, $\mathrm{MRR}=$ marginal rate of return; $\mathrm{D}=$ dominated treatments.

\section{Conclusion}

The experiment was conducted to determine the effect of row spacing and phosphorus fertilizer rate on mung bean yield and yield parameters. The results indicated that there were significant effects among treatments for plant height, total and effective number of nodule plant ${ }^{-1}$, pod plant ${ }^{-1}$, thousand grain weight, dry biomass yield and grain yield due to the application of phosphorus. Branch per plant, pod per plant, pod length and dry biomass yield were significantly $(\mathrm{P}<0.05)$ affected due to row spacing. The highest grain yield $(961.6 \mathrm{~kg}$ $\mathrm{ha}^{-1}$ ) was achieved from $46 \mathrm{~kg} \mathrm{P}_{2} \mathrm{O}_{5} \mathrm{ha}^{-1}$ while the lowest $\left(766.7 \mathrm{~kg} \mathrm{ha}^{-1}\right.$ ) was from $0 \mathrm{P}_{2} \mathrm{O}_{5} \mathrm{~kg} \mathrm{ha}^{-1}$. In conclusion, the application of $46 \mathrm{~kg} \mathrm{P}_{2} \mathrm{O}_{5} \mathrm{ha}^{-1}$ and $30 \mathrm{~cm}$ row spacing recorded highest grain yield with highest economic returns $\left(14123.78 \mathrm{ETB} \mathrm{ha}^{-1}\right)$. Based on grain yield and economic return, combination of $46 \mathrm{~kg} \mathrm{P}_{2} \mathrm{O}_{5} \mathrm{ha}^{-1}$ and $30 \mathrm{~cm}$ row spacing was recommended for the study area and similar agro-ecology.

\section{Acknowledgements}

I would like to thank Oromia Agricultural Research Institute and Fedis agricultural research center for financing and supporting the research. I am also most grateful to my colleagues who involved in research field work.

\section{References}

[1] Ahmad, S., Khan, A. A., Ali, S., Imran I. M. and Habibullah, M. 2015. Impact of Phosphorus Levels on Yield and Yield Attributes of Mung bean Cultivars under Peshawar Valley Conditions. Journal of Environment and Earth Science. Vol. 5, No. 1.

[2] Ajio, F., Talwana, H. \& Kagoda, F. 2016. Evaluation of Mung bean plant spacing for optimising yield in small holder cropping systems. RUFORUM Working Document Series No. 14 (2): 403- 406. Cape Town, South Africa.

[3] Amanullah, Majidullah, Asim Muhammad, Khalid Nawab and Asad Ali. 2016. Effect of tillage and phosphorus interaction on yield of mung bean (Vigna radiate L.) with and without moisture stress condition. International Scientific Researches Journal. Vol. 72 .

[4] Asian Vegetables Research and Development Centre (AVRDC), 1974. Mung bean Report for., 1973. Shanhua, Taiwan. pp: 23.

[5] Foysalkabir, A. K. M. Md. Quamruzzaman, Sheikh Mohammed, Mamur Rashid, MarjanaYeasmin and N. Islam. 2016. Effect of Plant Growth Regulator and Row Spacing on Yield of Mung bean (Vigna radiate L.). American-Eurasian J. Agric. \& Environ. Sci., 16 (4): 814-819.

[6] Gebrelibanos Gebremariam and Fiseha Baraki. 2018. Effect of Inter Row and Intra Row Spacing on Yield and Yield Components of Mung Bean (Vigna radiate L.) in Northern Ethiopia. International Journal of Engineering Development and Research. Volume 6, Issue 1. 2321-9939.

[7] Ghafoor, A., Ahmad, Z. and Qayyum, A. 2003. Black Gram (Vigna mungo L.) Germ plasm Catalogue. Plant Genetic Resources Prog. PARC/JICA, Islamabad, Pakistan, pp. 75-80.

[8] Graham, P. H. and Vance, C. P. 2003. Legumes: Importance and constraints to greater use. Plant Physiology, 131: 872-877.

[9] Hasanuzzaman, M., Nahar, K. and Fujita, M. 2013. Plant response to salt stress and role of exogenous protectants to mitigate salt-induced damages. In: Ahmad P, Prasad MNV (eds) Ecophysiology and Responses of Plants Under salt stress. Springer, New York. 25-87.

[10] Hedin, L. O., Vitousek, P. M. and Matson, P. A. 2003. Nutrient losses over four million years of tropical forest development. Ecology, 84: 2231-2255.

[11] Imran, Asad. A. K., Inamullah, I. and Fayaz, A. 2016. Yield and yield attributes of Mung bean (Vigna radiate L.) cultivars as affected by phosphorous levels under different tillage systems. Cogent Food \& Agriculture, 2: 1151982.

[12] Khan, M. M. S., Singh, V. P. and Kumar, A. 2017. Studies on Effect of Phosphorous Levels on Growth and Yield of Kharif Mung bean (Vigna radiata L.), Int. J. Pure App. Biosci. 5 (4): 800-808.

[13] Kumar, R., Y. V. Singh, S. Singh, A. M. Latare, P. K. Mishra and Supriya. 2012. Effect of phosphorus and sulphur nutrition on yield attributes, yield of mung bean (Vigna radiata L. Wilczek). Journal of Chemical and Pharmaceutical Research, 4 (5): 2571-2573. 
[14] Kumwenda, J. D. T., Waddington, S., Snapp, S. S., Jones, R. B. and Blackie, M. J. 1997. Soil fertility management in the smallholder maize based cropping systems of eastern and southern Africa. In Eisher $\mathrm{C}$ (eds.). The emerging maize revolution in Africa. Michigan State University: East Lansing, Michigan. pp. 153-172.

[15] Miah, M. H. N., M. A. Karin, M. S. Rahman and M. S. Islam, 1990. Performance of Nizershail under different row spacing. J. Train. Dev., 3: 31-34.

[16] Pookpakdi, A. and H. Pataradilok, 1993. Response of genotypes of mung bean and black gram to planting dates and plant population densities. Kasetsart J. Nat. Sci., 27: 395-400.

[17] Rasul, F., Cheema, M. A., Sattar, A., Saleem, M. F. and Wahid, M. A. 2012. Evaluating the Performance of Three
Mung bean Varieties Grown Under Varying Inter-Row Spacing. The Journal of Animal \& Plant Sciences, 22 (4): 1030-1035.

[18] Singleton, P. M., Abdel, H., Magid, M. and Tavares, J. W. 1985. Effect of $\mathrm{P}$ on the effectiveness of strains of Rhizobium japonicum. American Journal of Soil Science Society, 49: 613616.

[19] Tang C., Hinsiger, P. J. Drevonn, J. and Jailard, B. 2001. Phosphorus deficiency impairs early nodule functioning and enhance proton release in roots of Medicago truncatula $\mathrm{L}$. Annals of Botany, 88 (1): 131-138.

[20] Tekalign Tadese. 1991. Soil, plant, water, fertilizer, animal manure and compost analysis. Working Document No. 13. International Livestock Research Center for Africa, Addis Ababa. 